\title{
Biological properties and influencing factors of woolly apple aphid (Eriosoma lanigerum Hausm) in the condition of orchard agrobiocenosis
}

\author{
Nodir Sayimov ${ }^{1, *}$, Azimjon Anorbaev ${ }^{2}$, and Kalandar Bababekov ${ }^{1}$ \\ ${ }^{1}$ Scientific Research Center for Plant Quarantine, Tashkent, Uzbekistan \\ ${ }^{2}$ Tashkent State Agrarian University, University str., 2, Tashkent province, Uzbekistan, 100140
}

\begin{abstract}
This article provides information on the influence of biotic and abiotic factors on the development of the population of orchard agrobiocenosis of woolly apple aphid (Eriosoma lanigerum Hausm), the main sucking pest of seed orchards.
\end{abstract}

\section{Introduction}

It is well known that global climate change and population growth require the rational use of land resources [1]. Therefore, in recent years, the country has focused on ensuring food security through the efficient use of land resources [2]. The key to a successful solution to a food security program is to protect crops from pests, diseases and weeds. In order to ensure food security in our country, one of the most pressing issues today is the cultivation of ecologically clean, abundant and high-quality crops from orchards [3, 4]. Expansion of orchard areas, global climate change is leading to the mass development of woolly apple aphids [4].

Woolly apple aphid (Eriosoma lanigerum Hausm) is a common pest of Malus domestica apple all over the world. The biology of woolly apple aphid development in the apple tree throughout the year has been extensively studied in the United States [2]. In European countries, relatively little is known about woolly apple aphids, mainly in the Mediterranean region [5].

The most notable research in the study of the biology of woolly apple aphid in Central Asia was carried out by the well-known entomologists of the Turkestan entomology station V.I. Plotnikov (1914), I.A. Sevastyanov (1916), V.P. Nevsky (1925), Arkhangelsky (1939, 1949) [6-8], and biology of woolly apple aphid in the Crimea and the Caucasus: N.A. Porchinsky (1886, 1897), S.A. Mokrjetsky (1896), M. A. Parfentev (1924), I. Livshits, N. Petrusheva, S. Galetenko (1955); V.A. Glazunov (1929), L.P. Kalandadze (1930); M.N. Narzikulov (1948,1952), I.I. Stepantsev (1956), V.G. Baeva (1969) [4, 9].

Woolly apple aphid quickly adapts to the physiological-biochemical changes of the host plant organism, and this is expressed in polymorphism. All living forms of woolly apple aphid, native to North America, have survived in Europe as well. However, after the woolly

* Corresponding author: nodir.sayimov@yandex.com 
apple aphid entered Europe, it lost its main American sage plant owner and developed only in the apple, and each of its forms was adapted to live in the apple. [1, 10].

The primary host of the development cycle of woolly apple aphid in the eastern regions of North America - Ulmus artericana Mill.- is cultivated in the American sagebrush and its secondary intermediate host plant - Malus domestica Borkh. passes in the apple variety. Other host plants have also been recorded as intermediate. [5].

In Europe, woolly apple aphid does not live in the American squirrel, and even when the American squirrel was specifically damaged, it did not live in it. For example, P. Marchal (1919) in France, and O. Schneider (1926) in Germany (according to Mozgovoy Yu.G., 1937) attempted to infect American slate with woolly apple aphid, but to no avail [5].

The survival of the sap as a colony is important in protecting it from the cold in winter and various external factors. However, the role of cold temperatures in pest colonies in the Mediterranean region has not been investigated [8].

Woolly apple aphid feeds and damages apple trees. It causes direct damage by leaf curling, shedding, twisting of growing buds and systemic damage to the roots, fruit shedding, and deformation [7].

Also woolly apple aphid Eriosoma lanegirum feeds on the peel and root of the apple, weakens the plant, damages the injured areas, and causes cancer in older apple trees. The pest directly affects the fruits of some apple varieties. Woolly apple aphid also causes the appearance of black mold on the fruit during harvest. Simultaneously, trees can be damaged by arboreal (aboveground) and edaphic (root) colonies of woolly apple aphids. Arboreal colonies feed by damaging the leaf blade, wounds, and branches and twigs of apple trees. Edaphic colonies feed by sucking the roots and infecting them in this way [6,9].

Woolly apple aphids form colonies that easily settle on previously injured horns, twigs, and roots. It also feeds and forms colonies in undamaged (undamaged) areas [1,9].

\section{Materials and methods}

Surveillance and research on woolly apple aphids is more complicated. These complications are due to the small size of the syrups, which have a thick white glossy coating. Most importantly, his normal lifestyle is very sensitive to any changes and develops very quickly. They are unable to survive in artificial isolation and laboratory conditions due to colonial instinct.

Propagation of woolly apple aphids in seedlings planted in pots in the laboratory and conducting experiments on them is a more convenient method. After many attempts, we decided to use the following laboratory method. To do this, before the onset of the postwinter awakening season in early spring, in the morning, when the saplings did not come out of the dormant state, they were taken from the branches where they formed a colony.

The resulting woolly apple aphid were poured into a glass jar and tightly closed with a lid. As a result of collecting the woolly apple aphid, they were moved with a soft brush when moving the woolly apple aphid to prevent their sucker hairs from being torn off and killed.

In this way, in our experiments, from March to August, a continuous change of generations and the growth, communication, reproduction and other life phases of the first 10 generations were observed. In June-July, the rapid drying of the feed branches under the influence of high temperatures, the need for frequent transplanting had a negative effect on the sap, and there was a break between generations.

There were no difficulties with the sexes and wings of the lizards in the observations, deserts were needed for the lizards, otherwise they could have perished because they were constantly crawling on top of each other. Between the two pieces of apple peel or the cracks 
of the cut horn, even between two crumpled sheets of paper, the sexes felt good and developed normally.

Forms of root-infesting living under them were observed by repeatedly digging up the roots of diseased trees. Their cousins and illnesses - all carried out through direct observations in the wild.

\section{Results and discussion}

The biological properties of woolly apple aphid are significantly affected by environmental factors: temperature, humidity, and others. Woolly apple aphid is an insect that thrives in temperatures ranging from $15-30^{\circ} \mathrm{C}$ and $40-90 \%$ relative humidity. During our experiments, the effect of temperature and humidity on the development of woolly apple aphid was studied.

The experiments were carried out at temperatures of $15,20,25,30$, and $35^{\circ} \mathrm{C}$ and relative humidity in the range of $40-90 \%$. At a relative humidity of $70-90 \%$ and a temperature of $25-30^{\circ} \mathrm{C}, 2.5$ days to 3.5 days were required for the development of woolly apple aphids (Figure 1).

Relative humidity was $60 \%$, and even at a temperature of $20-25^{\circ} \mathrm{C}, 3.5$ to 5.0 days were required for woolly apple aphid proliferation and development. It was observed that the days of development of woolly apple aphids at $8 \%$ when the relative humidity was $50 \%$ and the temperature was $15-20$ and at $40 \%$ relative humidity were extended to 8 days.

At high $35^{\circ} \mathrm{C}$ temperatures and in any form of relative humidity, it was observed that the development rates of woolly apple aphid were low because: hot and dry air had the same negative effect on woolly apple aphid as cold air. Thus, in the range of optimal air temperature $20-30^{\circ} \mathrm{C}$ and relative humidity $60-90 \%$, it was found that the development rates of woolly apple aphids were high.

In Uzbekistan, woolly apple aphids feed in the form of large white colonies of larvae and adult wingless larvae and overwinter in all parts of the plant. But by the time of the spring awakening, very few of them and only some parts of the plants have survived. From the thick hairy colonies that completely cover the main trunks and branches of the trees in November, small columns with sparse, solitary cohesive and natural coverings remain until March. They are preserved in the underground parts of trees, cracks in the bark of thick branches, in the lower parts of the branches and in areas where the plant is well protected from winter rain. Elsewhere, in areas where there is frequent rainfall in the winter, the woolly apple aphid is completely destroyed, no matter how deep it penetrates between the bark of the tree or is covered with wax. According to some observers (Blanc, Kessler, Keller), larvae, which lay eggs in the fall, can overwinter. According to others, female larvae that do not hatch from eggs, on the other hand, eggs and juvenile females can overwinter. 


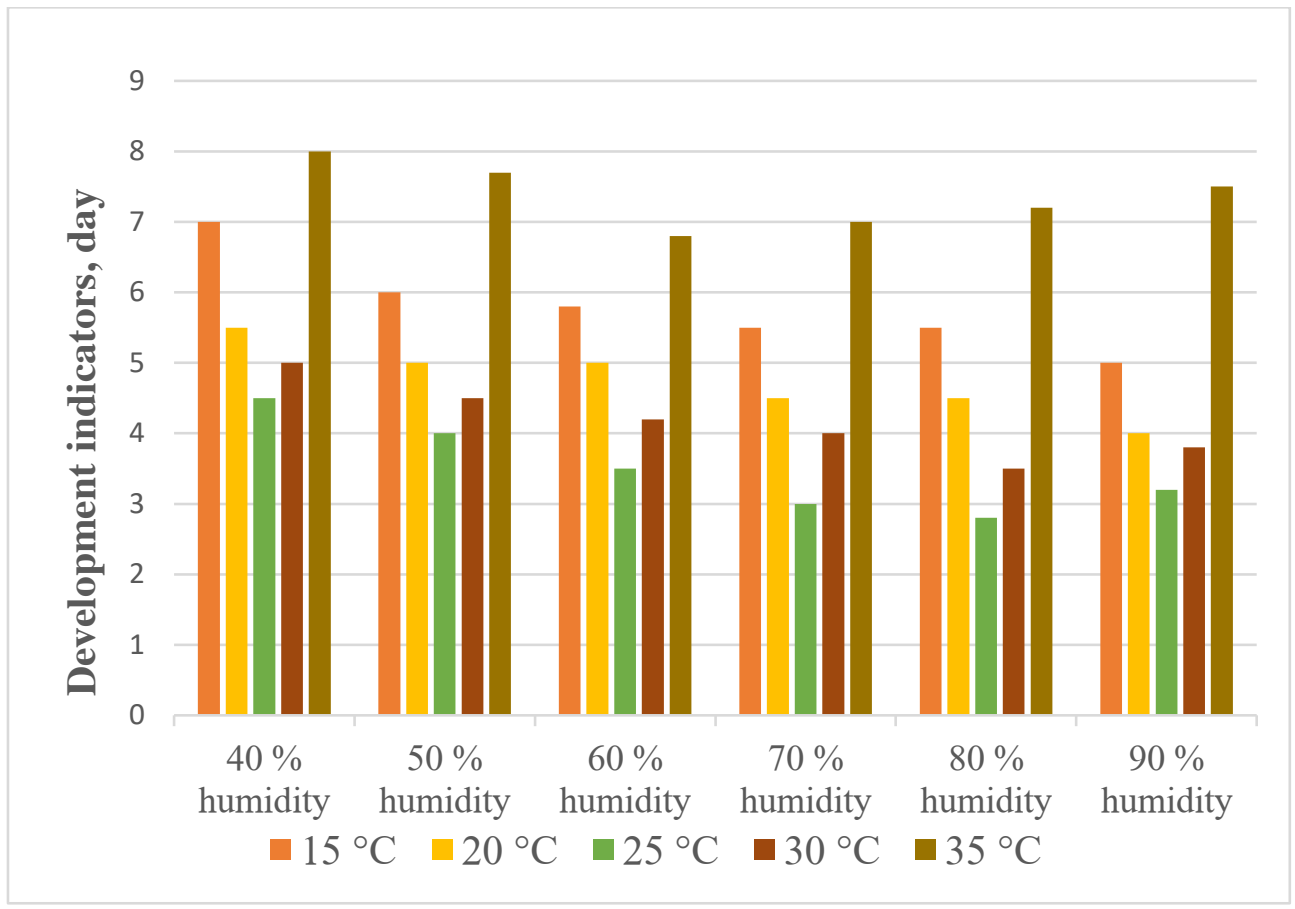

Fig. 1. Effect of temperature and humidity on the development of woolly apple aphids (SRCPQ, laboratory experience 2019-2020)

According to our observations, both larvae and adult females overwinter. But there are always more larvae than large larvae, and more newborn larvae than those that hatch from eggs. It all depends on the size of the winter sap and the location of the shelter. Small newborn larvae can easily live in any shelter, even under uneven bark, but large-sized larvae and adult aphids can perish here. Adult larvae and adult females survive in deep bark, inside the injured areas of the tree, in cracks in shelters. The following table shows the age status of the winter-emerging aphids, with data for 4 newly awakened aphids selected from various similar sources (Table 1). These data were obtained from experiments conducted on the basis of apple, pear and quince seedlings planted in an isolated pot in the garden.

Table 2. Description of aging period of woolly apple aphid (SRCPQ, laboratory experience, 2019-2020)

\begin{tabular}{|c|c|c|c|c|}
\hline \multirow{2}{*}{$\begin{array}{c}\text { Dates of } \\
\text { observation }\end{array}$} & \multicolumn{2}{|c|}{ 2019 } & \multicolumn{2}{c|}{ 2020 } \\
\cline { 2 - 5 } March 7 & $\begin{array}{c}\text { One larva is } \\
\text { isolated }\end{array}$ & $\begin{array}{c}\text { One larva is } \\
\text { isolated }\end{array}$ & - & No.4 \\
\hline March 18 & Peeling off & - & - & - \\
\hline March 19 & - & Peeling off & - & - \\
\hline March 25 & Peeling off & - & - & - \\
\hline March 31 & - & Peeling off & - & $\begin{array}{c}\text { One larva is } \\
\text { isolated }\end{array}$ \\
\hline April 4 & - & - & $\begin{array}{c}\text { One larva is } \\
\text { isolated }\end{array}$ & - \\
\hline April 5 & Peeling off & - & - & - \\
\hline
\end{tabular}




\begin{tabular}{|c|c|c|c|c|}
\hline April 6 & - & $\begin{array}{c}\text { Peeling off; } \\
\text { Beginning of } \\
\text { birth }\end{array}$ & - & - \\
\hline April 8 & Peeling off & - & Peeling off & $\begin{array}{c}\text { Beginning of } \\
\text { birth }\end{array}$ \\
\hline April 9 & $\begin{array}{c}\text { Beginning of } \\
\text { birth }\end{array}$ & - & - & - \\
\hline April 12 & - & - & $\begin{array}{c}\text { Beginning of } \\
\text { birth }\end{array}$ & - \\
\hline
\end{tabular}

Note: No. 1 - unpeeled off larvae overwintered; No. 2 - peeled off once; No. 3 -peeled off triple; and No. 4 - mature female

As can be seen from the table data, young larvae that did not shed under the first column were observed, and these larvae began to give birth after four ovulations. The observed woolly apple aphid under the second column began to give birth after one more ejaculation and three more ejaculations. The lizards observed under the third and fourth pillars gave birth three times and were adult females, while the lizards under the third pillar began to give birth after one litter, while the lizards under the fourth column began to give birth without shedding as adult lizards over four years old. Studies show that one generation of woolly apple aphids is four years old.

Our research on the biological characteristics of woolly apple aphid entomophagous species in Tashkent and Samarkand regions and the formation of host-entomophagous relationships in agrobiocenosis shows that in the management of woolly apple aphid in orchard agrobiocinosis, parasitic woolly aphid infestation was observed in $48 \%$ of its natural entomophagous species. Lacewing and seven-dotted lady bug entomophagous species were observed to reduce woolly apple aphid by an average of $19 \%$, while stethorus entomophagous species were observed to be reduced by up to $15 \%$. One of the main reasons why orchids are more susceptible to woolly apple aphid infestation with woolly aphid parasite than other predatory entomophagous in agrobiocytosis is that the woolly aphid predator is an oligophagous entomophage and is associated only with apple woolly apple aphid infestation (Figure 2). 


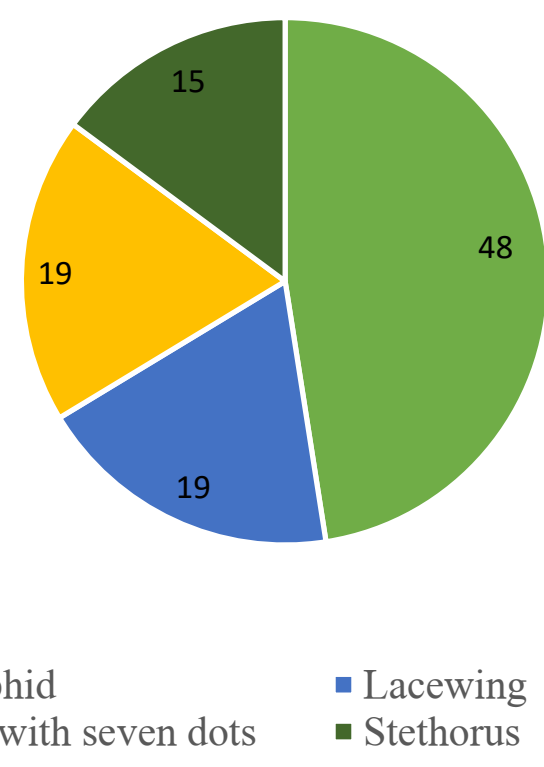

Fig. 2. Degree of infestation of woolly apple aphid with parasites and wild entomophagous species in natural conditions (Tashkent and Samarkand provinces 2018-2020)

\section{Conclusion}

Woolly apple aphid with over four years of age begins to give birth live and develop rapidly at favorable air temperatures, which adversely affect the yield and quality of apple fruit. In order to prevent these cases, one of the urgent tasks today is to carry out biological control of woolly apple aphids on the basis of beneficial entomophagous.

Biologically, it plays an important role in pest control by not adversely affecting the environment and food quality. The need for biological control in the management of apple woolly apple aphid population in apple orchard agrobiocinosis is a requirement of today. Thus, the introduction of natural couscous as a biological control tool to reduce pests in apple orchards is becoming increasingly important in the control of woolly apple aphid.

\section{References}

1. E. H. Beers, S. D. Cockfield, G. Fazio, IOBC-WPRS Bulletin 30, 37-42 (2007)

2. E. H. Beers, S. D. Cockfield, L. M. Gontijo, Envi. Entomology 39, 286-294 (2010)

3. C. Bomer, Anz. Schodlingsk 8, 52-54 (1999)

4. M. W. Brown, J. J. Schmitt, J. Econ. Entomol. 83, 1526-1530 (1990)

5. J. M. Heunis, K. L. Pringle, African Entomology 14, 77-86 (2006)

6. X. M. Tan, Z. S. Yang, H. Zhou, Q. M. Yang, H. X. Zhou, Arthropod-Plant Interactions, 1-11 (2021)

7. N. F. Stokwe, A. P. Malan, African Entomology 25(1), 123-136 (2017)

8. J. Singh, S. Bhardwaj, Indian Journal of Entomology 80(2), 353-355 (2018) 
9. J. Singh, R. S. Chandel, P. L. Sharma, Proceedings of the National Academy of Sciences, India Section B: Biological Sciences 88(1), 383-390 (2018)

10. V. Kumar, D. Gupta, Indian Journal of Entomology 81(3), 467-471 (2019) 